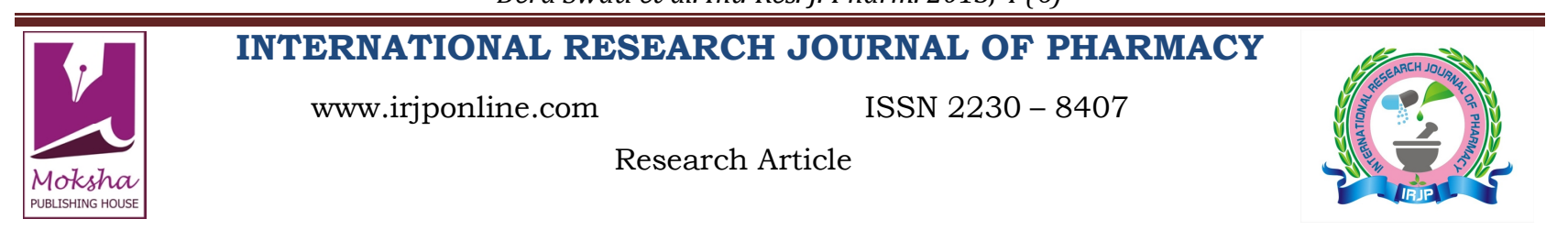

\title{
ANTI-THYROID PEROXIDASE ANTIBODY LEVEL IN THYROID NODULES: WITH SPECIAL REFERENCE TO THYROID NEOPLASIA
}

Bera Swati ${ }^{1}$, Gupta Soma ${ }^{2}$, Dutta Sumanta $\mathrm{K}^{3}$, Chowdhury Kanika ${ }^{4}$, Bhattacharyya Swati ${ }^{5}$, Saha (Das) Mita ${ }^{1}$

${ }^{1}$ Department of Biochemistry, WBUHS, R. G. Kar Medical College, Kolkata, West Bengal, India

${ }^{2}$ Department of Biochemistry, WBUHS, College of Medicine \& Sagore Dutta Hospital, Kolkata, West Bengal, India

${ }^{3}$ Department of E.N.T, WBUHS, Calcutta National Medical College, Kolkata, West Bengal, India

${ }^{4}$ Department of Biochemistry, WBUHS, Burdwan Medical College, Burdwan, West Bengal, India

${ }^{5}$ Department of Biochemistry, WBUHS, Medical College, Kolkata, West Bengal, India

*Corresponding Author Email: guptasomarusa@yahoo.com

Article Received on: 13/03/13 Revised on: 07/04/13 Approved for publication: 12/05/13

DOI: 10.7897/2230-8407.04633

IRJP is an official publication of Moksha Publishing House. Website: www.mokshaph.com

(C) All rights reserved.

\section{ABSTRACT}

Anti-TPO antibody level was evaluated in 86 patients, along with 25 healthy controls to detect its change in various forms of thyroid nodules particularly in thyroid malignancy when compared with healthy controls. The study revealed that Anti-TPO antibody level was increased in Benign \& toxic form of Multi nodular goiter and papillary carcinoma but there is no elevation of Anti- TPO antibody level in follicular adenoma or follicular carcinoma.

Keywords: Anti TPO antibody, thyroid neoplasia, nodular goiter.

\section{INTRODUCTION}

Thyroid disorders, the second commonest endocrine disorder often present as solitary or multi nodular goiter ${ }^{1}$. Multi nodular goiter (MNG) may be toxic or non toxic, the later being the most prevalent thyroid pathology ${ }^{2}$. The evaluation of thyroid nodule is of prime importance as neoplasm of thyroid most commonly present as mass or nodular lesion ${ }^{3}$. Thyroid nodules may be benign (adenoma) or malignant. The 3 major histological types of thyroid adenoma are papillary, follicular \& Hurthle cell type whereas papillary carcinoma and follicular carcinoma are major histological varieties of thyroid malignancy. Thyroid disease occurs in $4-7 \%$ of population and thyroid nodules have $5-15 \%$ prevalence of malignancy ${ }^{4}$. Another important presentation of goiter is Hashimoto's disease which is an autoimmune thyroiditis where high titre of anti TPO antibody (Ab) is always present. Evaluation of thyroid nodules requires detailed history taking, careful examination, Ultrasound examination and Fine needle aspiration cytology (FNAC). FNAC of thyroid nodules is accurate, sensitive and specific procedure, as well as cheap. However, one of the commonest drawbacks of FNAC is that it cannot differentiate follicular adenoma from follicular carcinoma, which requires the need of histopathological diagnosis of the whole nodule ${ }^{5}$. The second most common drawback of FNAC is inadequacy of sample and nodules have to be re-aspirated ${ }^{6}$. Radio iodine uptake (RAIU) is the only direct test of thyroid, but nowadays it is not much in use as there is improvement of various indirect methods for assessing thyroid status ${ }^{7}$. Thyroid Peroxidase (TPO) enzyme is essential for biosynthesis of thyroid hormone. TPO protein has been demonstrated to get expressed in benign \& normal thyroid tissue but is absent or poorly expressed in a variety of thyroid follicular carcinoma ${ }^{8}$. In this backdrop, this study is aimed to find out the level of anti-thyroid peroxidase (Anti-TPO) antibody in different forms of goiter and to detect whether it can be used as a marker in thyroid neoplasia.

\section{MATERIAL AND METHODS}

The study was carried out at Department of Biochemistry, R.G. Kar Medical College \& Hospital in collaboration with Department of ENT, Calcutta National Medical College from March 2011 till February 2012. A total of 86 newly diagnosed patients presenting with nodular goiter were included in the study. Those patients who were already under treatment and who were managed conservatively were excluded from the study. After careful history taking, $4 \mathrm{ml}$ of blood was collected in a plain vial from 86 cases and 25 age and sex matched healthy controls after overnight fasting. The serum was separated and used for estimation of FT4 ${ }^{9}, \mathrm{TSH}^{10}$ and Anti-TPO antibody ${ }^{11}$ by micro plate enzyme linked immunosorbent assay using the kit of Accubind. The patients included in the study population were asked to report again after obtaining the histopathological report. Based on these reports the patients were classified into 4 groups, namely, colloid goiter, solitary nodule (sub grouped into follicular adenoma, papillary carcinoma \& follicular carcinoma), multi nodular goiter (MNG, sub grouped into toxic and non toxic MNG) and Hashimoto's goiter. Biochemical parameters were tabulated accordingly and analyzed using Microsoft Excel, 2010 .

\section{RESULT}

Table 1 shows the distribution of study population according to gender \& histopathological classification. Though overall 86 patients were included in the study, after histopathological classification, maximum number of patients in one group was not more than 20 . Hence number of healthy controls taken was 25. Table 2 shows levels of Biochemical parameters, namely FT4, TSH and Anti TPO Antibody (Expressed as mean \pm S.D. $)$ in the study population. Considering the levels of FT4 \& TSH, it was observed that colloid goiter cases were euthyroid, Toxic MNG cases were hyper thyroid and all other varieties were mostly hypothyroid. Anti TPO Antibody level was found to be high in papillary carcinoma and both, toxic $\&$ benign MNG. Since the standard deviation was very high, a cut off value of this parameter was obtained considering the 
Bera Swati et al. Int. Res. J. Pharm. 2013, 4 (6)

2 standard deviation of positive side of the mean level in 3 shows the distribution of study population according to healthy control, which was calculated to be $21.6 \mathrm{IU} / \mathrm{ml}$. Table level of Anti TPO Ab.

Table 1: Distribution of study population according to gender \& histopathological classification

\begin{tabular}{|c|c|c|c|}
\hline \multicolumn{2}{|c|}{ Histopathology of goiter } & Male & Female \\
\hline \multicolumn{2}{|c|}{ Healthy control $(\mathrm{n}=25)$} & 5 & 20 \\
\hline \multicolumn{2}{|c|}{ Colloid goiter $(\mathrm{n}=10)$} & 1 & 9 \\
\hline \multirow{4}{*}{$\begin{array}{c}\text { Solitary nodule } \\
(\mathrm{n}=34)\end{array}$} & $\begin{array}{c}\text { Follicular Adenoma } \\
(\mathrm{n}=10)\end{array}$ & 2 & 8 \\
\cline { 2 - 4 } & $\begin{array}{c}\text { Papillary carcinoma } \\
(\mathrm{n}=14)\end{array}$ & 4 & 10 \\
\cline { 2 - 4 } & $\begin{array}{c}\text { Follicular carcinoma } \\
(\mathrm{n}=10)\end{array}$ & 3 & 7 \\
\hline $\begin{array}{c}\text { Multinodular goiter } \\
(\mathrm{n}=32)\end{array}$ & $\begin{array}{c}\text { Toxic MNG } \\
(\mathrm{n}=20)\end{array}$ & 4 & 16 \\
\cline { 2 - 4 }$(\mathrm{n}=12)$ & 2 & 10 \\
\hline \multicolumn{2}{|c|}{ Non toxic (Benign)MNG } \\
\hline \multicolumn{2}{|c|}{ Hashimoto's goiter $(\mathrm{n}=10)$} & 2 & 8 \\
\hline
\end{tabular}

Table 2: Levels of Biochemical parameters (Expressed as mean \pm S.D.) in the study population

\begin{tabular}{|c|c|c|c|c|}
\hline \multicolumn{2}{|c|}{ Histopathology of goiter } & F T4 (ng/dl) & TSH (uIU/ml) & Anti TPO Ab IU/ml \\
\hline \multicolumn{2}{|c|}{ Healthy control $(\mathrm{n}=25)$} & $0.89 \pm 0.29$ & $1.67 \pm 0.86$ & $7.19 \pm 4.7$ \\
\hline \multicolumn{2}{|c|}{ Colloid goiter $(\mathrm{n}=10)$} & $1.09 \pm 0.2$ & $4.8 \pm 1.6$ & $5.71 \pm 2.3$ \\
\hline $\begin{array}{c}\text { Solitary nodule } \\
(\mathrm{n}=34)\end{array}$ & $\begin{array}{c}\text { Follicular Adenoma } \\
(\mathrm{n}=10)\end{array}$ & $0.93 \pm 0.34$ & $17.14 \pm 15.6$ & $13.4 \pm 9.9$ \\
\cline { 2 - 5 } & $\begin{array}{c}\text { Papillary carcinoma } \\
(\mathrm{n}=14)\end{array}$ & $1.01 \pm 0.6$ & $7.68 \pm 3.9$ & $206.86 \pm 71.7$ \\
\cline { 2 - 5 } & $\begin{array}{c}\text { Follicular carcinoma } \\
(\mathrm{n}=10)\end{array}$ & $1.41 \pm 0.3$ & $13.1 \pm 5.7$ & $5.9 \pm 1.4$ \\
\hline $\begin{array}{c}\text { Multinodular goiter } \\
(\mathrm{n}=32)\end{array}$ & $\begin{array}{c}\text { Toxic MNG } \\
(\mathrm{n}=20)\end{array}$ & $2.28 \pm 0.7$ & $0.19 \pm 0.1$ & $97.12 \pm 50.2$ \\
\cline { 2 - 5 } & $\begin{array}{c}\text { Non toxic (Benign)MNG } \\
(\mathrm{n}=12)\end{array}$ & $0.64 \pm 0.25$ & $36.83 \pm 11.7$ & $352.57 \pm 96.9$ \\
\hline \multicolumn{2}{|c|}{ Hashimoto's goiter (n=10) } & $0.54 \pm 0.32$ & $63.84 \pm 18.7$ & $377.71 \pm 87.6$ \\
\hline
\end{tabular}

Table 3: Distribution of patients according to level of Anti TPO Ab

\begin{tabular}{|c|c|c|c|}
\hline \multicolumn{2}{|c|}{ Histopathology of goiter } & $\begin{array}{c}\text { Number (\%) of study population with } \\
\text { Normal level of Anti TPO Ab }\end{array}$ & $\begin{array}{c}\text { Number (\%) of study population with } \\
\text { Elevated* level of Anti TPO Ab }\end{array}$ \\
\hline \multicolumn{2}{|c|}{ Colloid goiter $(\mathrm{n}=10)$} & $10(100 \%)$ & $0(0 \%)$ \\
\hline \multirow[t]{3}{*}{$\begin{array}{l}\text { Solitary nodule } \\
\quad(n=34)\end{array}$} & $\begin{array}{l}\text { Follicular Adenoma } \\
(\mathrm{n}=10)\end{array}$ & $08(80 \%)$ & $02(20 \%)$ \\
\hline & $\begin{array}{l}\text { Papillary carcinoma } \\
(\mathrm{n}=14)\end{array}$ & $02(14.3 \%)$ & $12(85.7 \%)$ \\
\hline & $\begin{array}{l}\text { Follicular carcinoma } \\
\qquad(\mathrm{n}=10)\end{array}$ & $08(80 \%)$ & $02(20 \%)$ \\
\hline \multirow[t]{2}{*}{$\begin{array}{l}\text { Multinodular goiter } \\
\qquad(\mathrm{n}=32)\end{array}$} & $\begin{array}{c}\text { Toxic MNG } \\
(\mathrm{n}=20)\end{array}$ & $04(20 \%)$ & $16(80 \%)$ \\
\hline & $\begin{array}{l}\text { Non toxic (Benign)MNG } \\
(\mathrm{n}=12)\end{array}$ & $02(16.7 \%)$ & $10(83.3 \%)$ \\
\hline \multicolumn{2}{|c|}{ Hashimoto's goiter $(\mathrm{n}=10)$} & $0(0 \%)$ & $10(100 \%)$ \\
\hline
\end{tabular}

\section{DISCUSSION}

Thyroperoxidase (TPO) is expressed in the surface of both normal and malignant thyroid cell. Thus, TPO expressed at the surface of the cancer cell can be recognized by Anti-TPO antibodies $^{12}$. TPO is the major auto antigen involved in autoimmune thyroid disease like Hashimoto's thyroid disease \& Graves' disease ${ }^{13}$. In the present study it was observed that Anti-TPO antibodies is elevated not only in patients suffering from Hashimoto's thyroiditis which correlates with the study of Chehade et $a l^{14}$, but also in cases suffering from MNG \& Papillary carcinoma. Anti-TPO expression level on papillary, follicular, anaplastic human thyroid cancer were tested by Rebuffat $e t a l^{12}$ and it was observed that TPO is present on all the cell lines, but it was less expressed in follicular and anaplastic carcinoma when compared to papillary carcinoma which was also observed by Czarnoca et al. ${ }^{15}$ This fact explains the present study where anti-TPO antibody was significantly elevated in papillary carcinoma and was within normal range in both follicular adenoma and follicular carcinoma. Azzi G \& Malchoff $\mathrm{CD}^{16}$ observed that thyroid cancer was not associated with elevated levels of anti TPO Ab. However, they did not mention any histopathological variety. Boi $\mathrm{F}$ et $a{ }^{17}{ }^{17}$ observed significant association between thyroid cancer and thyroid autonomy but no such was demonstrated by Samet $\mathrm{Y}$ et $a{ }^{18}{ }^{18}$. Rago $\mathrm{T}$ et $a{ }^{19}$ described that thyroid auto antibody was present in $23.7 \%$ cases with thyroid cancer \& $20.6 \%$ cases with benign lesion and the difference was not found to be significant. In the present study it was observed that elevated level of anti TPO $\mathrm{Ab}$ in $20 \%$ cases of follicular adenoma \& $20 \%$ cases of follicular carcinoma (Table 3). In a study by Fiore et $a l .{ }^{20}$, although no difference was observed between patients with benign thyroid nodular disease and patients with papillary thyroid cancer, it was established that serum levels of auto 
antibody increased with increasing severity of lymphatic infiltrations in thyroid cancer As far as MNG is concerned, we found elevated level of anti TPO Ab both in toxic and non toxic variety. Samet $\mathrm{Y}^{18}$ observed elevated level of anti TPO $\mathrm{Ab}$ in $12.7 \%$ cases. P. Vitti et al..$^{21}$ also observed elevated level of anti TPO Ab in benign MNG. They proposed that thyroid auto immune phenomenon was the consequence rather than the cause of the goiter.

\section{CONCLUSION}

The data in our present study indicate that Anti-TPO Ab level is elevated in multi nodular goiter (Both toxic \& non toxic) as well as in Papillary carcinoma of thyroid. However no significant difference in the level of the same parameter was observed in follicular adenoma \& carcinoma. Immunological basis in development of papillary carcinoma may be considered as a promising field of study.

\section{REFERENCES}

1. Shahulhameed S, Anjali S, Poulose PK. Prevalence of thyroid auto antibodies in young asymptomatic females: A pilot study. Thyroid Res Pract 2012; 9: 9-11. http://dx.doi.org/10.4103/0973-0354.92389

2. Frilling A, Liu C, Weber F. Benign multinodular goiter. Scandidavian Journal of Surgery 2004; 93: 278-281. PMid:15658668

3. Majjaferi EL. Thyroid cancer in thyroid nodules: finding a needle in a haystack. Am J Med 1992; 93: 359-362. http://dx.doi.org/10.1016/00029343(92)90163-6

4. Chavan A, Zeeshan M, Nikam A, Sundaresan S, Thangapannerselvan T. A prospective cohort study of nodular goiter: A Hormonal approach. Advances in Biological Research 2010; 4(5): 272-276.

5. Cummings C, Haugheu B, Thomas JR. editors-Cummings Otorhinolaryngology: Head and Neck Surgery. Philadelphia: Mosby Inc; 2005.

6. Gharib H, Goeliner JR. Fine needle aspiration biopsy of the thyroid: An appraisal. Ann Intern Med 1993; 118: 282-9. http://dx.doi.org/10.7326 /0003-4819-118-4-199302150-00007 PMid:8420446

7. Pearce EN, Farewell AP, Braverman LE. Thyroiditis. N Engl J Med 2003; 348: 2646-2655. http://dx.doi.org/10.1056/NEJMra021194 PMid: 12826640

8. Savin S, Cvejic D, Isic T, Paunovic I, Tatic S, Havelka M. The efficacy of the thyroid peroxidase marker for distinguishing follicular thyroid carcinoma from follicular adenoma, Exp Oncol 2006; 28(1): 70-74. PMid: 16614712

9. Nelson JC, Wilcox RB. Analytical performance of free and total thyroxine assay, Clin Chem 1996; 42: 146-154. PMid:8565218

10. Bravermann LE. Evaluation of thyroid status in patients with thyrotoxicosis, Clin Chem 1996; 42: 174-181.

11. Beever K, Bradbury J, Phillips D, et al. Highly sensitive assays of auto antibodies to thyroglobulin and to thyroid peroxidase. Clin Chem 1989; 35: 1949-54. PMid:2776323
12. Rebuffat SA, Morin M, Nguyen B, Castex F, Robert B, Peraldi-Roux S. Human recombinant anti- thyperoxidase antibodies: in vitro cytotoxic activity on papillary thyroid cancer expressing TPO. British Journal of Cancer 2010; 102: 852-861. http://dx.doi.org/10.1038/sj.bjc.6605464 PMid:20145622 PMCid:2833240

13. Mariotti S, Caturegli P, Picollo P, Barbesino G, Pinchera A. Antithyroid peroxidase auto antibodies in thyroid disease. The Journal of Clinical Endocrionology \& Metabolism 1990; 71(3): 661-669. http://dx.doi.org /10.1210/jcem-71-3-661 PMid:2168432

14. Czarnoca B, Pastuszko D, Janota-Bzowski M, Weetman AP, Watson PF, Kemp EH, Mc Intosh RS, Asghar MS, Jarzab B, Gubala E, Wolch J, Lange D. Is there or qulatative changesin the expression of thyroid peroxidase protein in thyroid epithelial cancer? Br J Cancer 2001; 85: 875-880. http://dx.doi.org/10.1054/bjoc.2001.2015 PMid:11556840 PMCid:2375069

15. Chehade JM, Lim W, Silverberg AB, Mooradian AD. The incidence of Hashimotos disease in nodular goiter: The concordance in serological and cytological findings. Int J Clin Pract 2010; 64(1): 29-33. http:/ /dx.doi.org/10.1111/j.1742-1241.2008.01942.x PMid:20089015

16. Azizi G, Malchoff CD. Autoimmune thyroid disease: a risk factor for thyroid cancer. Endocr Pract 2011; 17(2): 201-209. http://dx.doi.org/ 10.4158/EP10123.OR PMid:20841310

17. Boi F, Lai ML, Marziani B, Minerba L, Faa G, Mariotti S. High prevalence of suspicious cytology in thyroid nodules associated with positive thyroid auto antibodies. Eur J Endocrinol 2005; 153: 637-642. http://dx.doi.org/10.1530/eje.1.02020 PMid:16260421

18. Samet Y, Burak V Ulger, Omer Parlak, Ali Ercan Ucar, Seyyit Mushin Sarikaya, Mehmet Ozer, Birol Korukluoglu, Bulent Yalcin, Ahmet Kusdemir. The role of pre operative serum thyroglobulin and thyroid auto antibody level before histopathological diagnosis of thyroid cancers, Turk J Med Sci 2011; 41(3): 487-493.

19. Rago T, Di Coscio G, Ugoloni C, Scutari M, Basolo F, Latrofa F. Clinical features of thyroid autoimmunity are associated with thyroiditis on histology and are not predictive of malignancy in 570 patients with indeterminate nodules on cytology who had a thyroidectomy. Clin Endocrinol oxf 2007; 67: 363-9. http://dx.doi.org/10.1111/j.13652265.2007.02892.x PMid:17555501

20. Fiore E, Rago T, Scutari M, Ugolini C, Proietti A, Di Coscio G. Papillary thyroid cancer, although strongly associated with lymphocytic infiltration on histology, is only weakly predicted by serum thyroid auto antibodies In patients with thyroid auto antibodies in patients with nodular thyroid disease. J Endocrinol Invest 2009; 32: 344-51. PMid: 19636204

21. Vitti P, Mariotti S, Marcocci C, Chivalo L, Giachetty T, Fenzi G, Pinchera T. Thyroid autoimmunity and thyroid autonomy. Acta Med Austriaca 1990; 17(1) (suppl): 90-2. PMid:2202187

\section{Cite this article as:}

Bera Swati, Gupta Soma, Dutta Sumanta K, Chowdhury Kanika M, Bhattacharyya Swati, Saha (Das) Mita. Anti-thyroid peroxidase antibody level in thyroid nodules with special reference to thyroid neoplasia. Int. Res. J. Pharm. 2013; 4(6):150-152 